\title{
Conventional Occlusive Dressing versus Polythene Gloving on Second-Degree
}

\section{Burned Hands}

\author{
Amina Abdel Hamid Ebrahim, Preceptor \\ Medical Surgical Nursing, Faculty of Nursing, Alexandria University \\ Sanaa Mohamed Alaa Eldeen, Professor \\ Medical Surgical Nursing, Faculty of Nursing, Alexandria University \\ Hussein Saber Abulhassan, Professor \\ Plastic Surgery, Faculty of Medicine, Alexandria University \\ Fayza Mohamed Tawfeek, Lecturer \\ Medical Surgical Nursing, Faculty of Nursing, Alexandria University
}

\begin{abstract}
Burns are the most devastating injuries that can occur. The location of burn influence healing as burns to face, neck, hands and feet. Regarding hands, its represent a small wound area, although a major potential for disabilities as stiffness and contracture. The aim of burned hand treatment is to achieve healing in shortest possible time without producing disabilities. However burned hand can be treated with occlusive dressing, but it may associate with finger stiffness after prolonged immobilization. There are other methods can be used; the non-occlusive dressing as plastic bag or glove, they have the advantages of ease to use, allow ability to observe the hand, providing a good healing environment with good wound healing. Objective: Compare the effectiveness of two dressing techniques, conventional occlusive dressing versus polythene gloving on second degree burned hands. Setting: The study was carried out at the burn unit of the main university hospital in Alexandria. Subjects: A convenient sample of 40 patients admitted to burn unit suffering from second-degree burned hands was included in this study. The subjects were selected according to the following criteria: adult of both sexes, able and willing to cooperate and communicate, newly admitted with recent burns. Patient with co-morbid disease, associated trauma, escharatomy was excluded from this study. Forty patients that included in the study were divided randomly into two groups of equal size (20 patients, each). The first 20 patients were managed by conventional occlusive dressings. The second 20 patients were managed by polythene gloving. Tools: Two tools were used for data collection. The first tool (Burn Patients Assessment and Follow-Up Sheet) comprised three parts (1) Biosociodemographic data, (2) Burn wound assessment, (3) Bacteriological studies. Tool two the Burned Hands Daily Living Activities (DLAs) Observation Checklist including 8 items.. Results: In the present study (70\%, 80\%) were workers respectively in conventional occlusive and polythene gloves groups. The results of this study found no statistically significant differences between conventional occlusive and polythene gloving techniques regarding the wound healing process (granulation and epithelialization) and infection rate. However, polythene gloving was painless, less time consuming, low cost and allowing for daily living activities as compared with conventional occlusive technique. Conclusion: The results of this study denotes that using polythene gloving is more quick, painless, less time consuming and allowed for daily living activity (DLAs) which promote in dependency in patient with burned hands. Recommendations: Studies effect of polythene gloves dressing on second degree burned hands/hand at outpatient and on 3rd degree burned hand.
\end{abstract}

Keywords: Conventional Occlusive Dressing, Polythene Gloving, Burned Hands. 


\section{Introduction}

A burn has been defined as loss of continuity of body surface due to coagulation and destruction of the skin and/or underlying tissues. This is due to exposure of the cells to a temperature incompatible with cell life ${ }^{(1,2)}$.

The two most important elements in evaluating a burn are the degree or depth of damage and the extent of involvement. In the past, burns were defined by degrees as first, second, and third degree. However, the newer classification is based on the depth of involvement as superficial, partial thickness, and full thickness burns ${ }^{(3,4)}$. The categories of superficial, partial thickness, and full thickness burns are similar to first, second, and third degrees burns ${ }^{(5)}$.

Regarding Second-degree (partial thickness) burn can be subdivided into superficial partial thickness and deep partial thickness ${ }^{(6)}$. Superficial partial thickness burns involve the epidermis and part of the dermis. This is usually characterized by the blister formation, very painful, moist surface with pink or red mottled appearance. It can expect to heal within fourteen days ${ }^{(7)}$. Deep partial burns involve the entire epidermis, but extend much deep into the dermis. They are usually characterized by blister, dark red with yellow-white patches, pain, and healing usually takes place within 3-4 weeks ${ }^{(8)}$.

The burn healing is the same for all wounds, whether the cause is mechanical, chemical or thermal ${ }^{(9)}$. The wound healing process consists of a serious of highly complex, interdependent, and over lapping stages; initiated by tissue trauma that can be divided into three phases: defensive, proliferative and maturation ${ }^{(10,11)}$.

Hampson (2002), and Perry and Potter (2006) mentioned that the first phase is the defensive phase, which considers the body's first response to injury with hemostasis and inflammation ${ }^{(12,13)}$. This phase is marked by redness, warmth, pain and edema at the wound site. Redness and warmth are due to vasodilatation of surrounding intact blood vessels and increased blood supply to the $\operatorname{area}^{(14)}$. Inflammation may be extending for 4-6 days depending on the extent of the injury and prolonged in infected wounds ${ }^{(15)}$.

The second phase of wound healing is the proliferation phase. The desired outcomes of this phase are to fill the wound defect with connective tissue, and cover it with epithelium. This phase characterized with: Granulation, contraction and epithelialization ${ }^{(16)}$. Production of new blood vessels which evident by third day and is most active by seven day and connective tissue, creates granulation tissue, which appears bright red ${ }^{(17)}$. The estimated overall duration of the proliferation phase from day 3 to 21 days in a normally healing full thickness ${ }^{(15)}$.

The final and the third phase of wound healing is the maturation phase; this phase extends from 21 day to 2 years $^{(18)}$. Fully healed tissue will achieve, at least, approximately $80 \%$ of its original strength. When changing a dressing the nurse must be knowledgably about wound healing in order to differentiate a normal or expected appearance from abnormal changes ${ }^{(13)}$.

Burns of the hands, feet, joints, and eyes are of concern because they make selfcare very difficult and may jeopardize future function. Circumferential burns of the extremities can cause circulatory comprise distal to the burn with subsequent neurological impairment of the affected extremity $^{(3)}$.

Abd El-Mohsen (2008) states that there are two main clinical types of hand burns: exposed-burn mainly on the dorsal aspect and contact-burn mainly on the volar surface. Volar hand burns usually occur in children exploring hot objects. Dorsal hand burns are common, usually affecting both hands. As the hand by reflex action clenches and covers the face during occurrence of the injury. The back of the hand can't however; be protected by the mechanism of 
clenching ${ }^{(19)}$. Burn to the hand is one of the most devastating physical and psychological injuries $^{(20,21)}$. Although the hands constitute only $5 \%$ of the total body surface area (TBSA), the upper extremity and hand are the most frequently injured part of the human body ${ }^{(22)}$.

Although the hand comprises a small surface area, management of a hand burn assumes a high priority to maintain maximum functional restoration of the hand ${ }^{(23,24)}$. The management of burned hands, particularly in cases of first and superficial second-degree burns, should be directed at the prevention of swelling, the preservation of mobility and protection of the wound so that healing can occurs. In cases of deep second-degree and thirddegree burns, surgical intervention may need to be considered ${ }^{(25)}$. The superficial and moderately deep second-degree burns of the hand can usually be given ambulant treatment. However, such burns need some kind of a dressing both to protect the burn and to promote healing ${ }^{(22)}$.

The hand and fingers tolerate injury and immobilization poorly and thus immediate and appropriate medical attention is of paramount importance as delay of treatment can have dire long term consequences $^{(26)}$. The aim in all forms of burned hand treatment is to achieve healing in shortest possible time without producing stiffness or contracture. However, there are two schools of thoughts as to the basic principles underlying the treatment of these burns. One has stressed the importance of early healing rather than early movement, whilst the other proposed otherwise and insisted on early movement before the hand is healed to prevent stiffness ${ }^{(27)}$.

Burned hand care includes once or twice-daily wound cleaning and debridement, application of topical antimicrobial agents, and dressings ${ }^{(28)}$. Dressings can, in general terms, be of two types: occlusive or non-occlusive dressing ${ }^{(29)}$. In occlusive dressing, gauze of various types is used. Occlusive dressing are thin gauze that is either impregnated with a topical antimicrobial or applied after topical antimicrobial application ${ }^{(30)}$. Dressing for fingers should be wrapped separately or folded pieces of dry gauze should be placed between the digits to separate them. A good time for exercise of fingers is during and after wound cleaning, when the skin is softer and bulky dressings are removed ${ }^{(29)}$.

Other methods can be used, the nonocclusive dressing. The main non-occlusive dressing in use is a bag. Plastic bags are commonly used. They have the advantage of ease to use and effectiveness in providing a good healing environment with good hand mobility ${ }^{(25)}$.

Raftarg (2001) say that, the polythene gloves can be used instead of bag, which is securely taped to the wrist or forearm proximal to the edge of the burned area ${ }^{(31)}$. A large dressing pad should be taped around the wrist inside the bag or gloves to soak up to absorb exudates. The hand then elevated and the patient-encouraged to exercise the hand continuously, keeping all the joints going to the maximal extent consistent with avoidance of real discomfort ${ }^{(32)}$.

Following the advantages found by Belcher (1995), that; the use of polythene gloves in treating hand burns is quick, easy and comfort, also allows ability to observe the hand, more digital movement whilst healing occurs and give the patients a much higher degree of independence ${ }^{(33)}$.

The present study will be conducted in order to evaluate the effect of using the conventional occlusive dressing versus polythene gloving in patients with seconddegree burned hands.

\section{Aim of the Study}

The aim of the study was to compare the conventional occlusive dressing versus polythene gloving on second-degree burned hands. 


\section{Research Hypotheses:}

1. Burned hand managed by polythene gloving techniques had a positive effect on wound healing than conventional occlusive dressing.

2. Burned hand managed by polythene gloving technique had a positive effect on practicing DLAs than conventional ones.

\section{Materials and Method}

\section{Materials}

Design: A quasi-experimental design was utilized to meet the aim of the study.

Setting: This study was conducted at the burn unit of Alexandria Main University Hospital.

Subjects: A convenient sample of 40 patients admitted to burn unit suffering from second-degree burned hands. The patients were selected according to the following criteria: adult of both sexes, able and willing to cooperate and communicate, newly admitted with recent second-degree burns. Patient with co-morbid disease, associated trauma, escharatomy was excluded from this study.

Forty patients that included in the study were divided randomly into two groups of equal size (20 patients, each). The first 20 patients were managed by conventional occlusive dressings. The second 20 patients were managed by polythene gloving.

Tools: In order to achieve the aim of the study the following two tools were developed by the researcher based on review of relevant literature:

\section{Tool I: Burn Patients Assessment and Follow-Up Sheet}

It was comprised of three parts:

Part I: Included data related to
$\begin{aligned} & \text { Biosociodemographic data: it was } \\ & \text { developed to collect: }\end{aligned}$

a- Personal characteristics: it included data as Patients' age, sex, level of education, occupation.

b- Clinical data including hospital number, date of burn, date of admission, date of discharge and patient habits.

- Cause of burn, Total body surface area (TBSA), affected hand/ hands.

- Medication related data.

- Laboratory investigation: included hemoglobin, hematocrit, total leukocyte (WBCs), total protein, serum albumin, and albumin/globin ratio.

- Anthropometric measurements: these included patients weight (kg), height (meters), and body mass index (BMI; in $\mathrm{kg} / \mathrm{m}^{2}$ ).

Part II: It included data related to burn wound assessment: This part was developed to evaluate burn wound healing and determine signs of infection in both groups to detect the extent of healing at $1^{\text {st }}, 2^{\text {nd }}$, and $3^{\text {rd }}$ week post burn. It included items as:

1. Wound color: red, white, black, green, or yellow.

2. Appearance of wound:

- Re-epithelialization, granulation.

3. Signs of infection:

- Tenderness, erythema, purulent discharge.

- Conversion of 2nd degree burn to 3rd degree burn \& brown or black discoloration of wound.

4. Presence of exudates:

- Type: serous, sanguineous or purulent.

- Amount: no discharge, mild, moderate or profuse.

- Odor: offensive or not. 
Part III: Bacteriological wound studies:

Post burn culture was taken from wound on the $4^{\text {th }}$ day and then weekly until healing occurs. It consisted of four columns, (1) methods of dressing, (2) result of first swab for bacterial culture on the $4^{\text {th }}$ day post burn, (3) result of second swab for bacterial culture on the $11^{\text {th }}$ day post burn, (4) result of third swab for bacterial culture on the $18^{\text {th }}$ day post burn. Columns 2, 3, 4 were divided into 3 parts for types of microorganisms (gram -ve or gram +ve) and sensitivity to antibiotics. This sequence of bacteriological studies was chosen according to Sommers (2000), who reported that by the $4^{\text {th }}$ or $5^{\text {th }}$ post burn day, burn wounds generally contain colonized bacteria $^{(119)}$.

\section{Tool II: The Burned Hands Daily Living} Activities (DLAs) Observation Checklist

Include 8 items: dressing gown, turning on/off taps, cleaning teeth, cutting bread, using spoonful, moving heavy cans, putting in/ taking out electric plugs and turning pages. Each activity was graded on level of dependence which graded via score threepoint rating scale ${ }^{(121,122)}$. Checking of the listed items was done on the $5^{\text {th }}$ day after inflammatory stage subsides, then followed up on $9^{\text {th }}, 13^{\text {th }}, 17^{\text {th }}, 21^{\text {st }}$ day post burn.

The scoring system for DLAs rating scale; the total patient's responses were summed up then converted into percentage as the following:

More than $70 \%$--------consider good.

From 60-70\%--------consider satisfactory.

Below60\%--------consider unsatisfactory.

\section{Method}

- A written approval to carry out the study was obtained from the hospitals authorities and head of department of the study setting at Alexandria Main University Hospital.
- The developed tools were designed based on the review of relevant literature. The tools were tested for content validity by ten experts from field of the study; five from each (Medical-surgical nursing professors and Plastic surgeons). The required modifications were carried out accordingly.

- A pilot study was conducted on five patients affected by hand burn, to test clarity, applicability of developed tools.

- Data was collected within seven months, during the period between January and July 2008. Patients' hospital records were received in order to determine admission date, date of burn, initial diagnosis and treatment. Every burned patient admitted to the burn unit and met the selection criteria were contacted and asked to participate in the study. The conventional occlusive dressing group was completed first, and the next twenty patients were included into polythene gloves group.

- A group of forty burned hand patients constituted the sample after obtaining their consent for participation.

- Wound condition was assessed using Tool 1: Part II on admission then weekly by the researcher, at $1^{\text {st }}, 2^{\text {nd }}$, and $3^{\text {rd }}$ week post burn, to evaluate the progress of wound healing and recording signs of wound healing or infection when present.

- Patient was assessed for doing DLAs by burned hand/hands at evening before dressing using tool II on the 5th day post burn and followed on 9th, 13th, 17th, 21st day post burn. The time ranged between 15 to $20 \mathrm{~min}$ for each patient in each visit. 


\section{Ethical considerations:}

Patient's consent for participation was obtained to carry out the study and each patient was informed about the purpose of the study.

\section{Statistical Analysis}

Data of the obtained result were tabulated and presented in frequency distribution tables. Data analysis was carried out by computer using the SPSS. Correlations were tried in between the essential studied parameters. The statistical analysis included: the mean, standard deviation, chi-qure $\left(\chi^{2}\right)$, fisher exact test (FET), and Monte Carlo test. The level of significant for the study was $\mathrm{p}<0.05$.

\section{Results}

Table (1) showed the studied patients in both conventional occlusive dressing and polythene gloves dressing according to their biosociodemographic variables upon admission.

The main results of this table have revealed that, the largest percentage of patients $(60 \%$ and $75 \%$ respectively) were males and less than two third and half of the conventional occlusive and polythene gloves groups (60\%-50\%) respectively were in age 18-25 years. Regarding education, it was found that $50 \%$ of patient in conventional group was illiterate, while $45 \%$ in polythene gloves group was read and write. More than two thirds of the patient in conventional and polythene gloves groups $(70 \%$ and $80 \%$ respectively) was involved in manual work.

Table (2) showed the studied patients in both conventional occlusive dressing and polythene gloving dressing in relation to cause of burn, current medication received and body mass index.

This table revealed that, flame was the main cause among the majority of patient in conventional group and polythene gloves group ( $85 \%$ and $90 \%$ respectively).
Also all of the studied patients in both groups managed by the same medications during their course of treatment as corticosteroids, anti-inflammatory and antibiotics. While corticosteroids were prescribed for the majority of the patients in conventional group and polythene gloves group ( $85 \%$ and $95 \%$ respectively).

As regards body mass index (BMI), 55\% of the conventional group and $60 \%$ of the polythene gloves group patients had normal body weight. While, $45 \%$ of the conventional group patients and $40 \%$ of the polythene gloves group had over weight upon their admission.

The table also illustrates that the mean percentage of TBSA for patients in both conventional and polythene gloves dressing groups were (19.25 and 19.30 respectively).

Table (3) showed distribution of studied patients in both conventional occlusive dressing and polythene gloves groups according to laboratory investigations at $1 \mathrm{st}$, 2nd and 3rd week.

The table shows that $85 \%$ of patient in the conventional group and $90 \%$ of the polythene gloves group had normal level of haemoglobin at $1^{\text {st }}$ week. While, $75 \%$ and $80 \%$ of patient in both the conventional and polythene gloves groups respectively had normal haemoglobin value at $2^{\text {nd }}$ week. Moreover, haemoglobin value was normal in $75 \%$ and $50 \%$ of the patient in both groups respectively at $3^{\text {rd }}$ week.

For WBCs, the majority of patient in both studied groups at $1^{\text {st }}$ week and $2^{\text {nd }}$ week were abnormal. On the contrary, at $3^{\text {rd }}$ week (75\% and $100 \%)$ of both conventional and polythene gloves groups had normal value regarding WBCs.

The table also revealed that the largest percentage of patients in both conventional and polythene gloves groups $60 \%$ and $80 \%$ recorded normal value regarding albumin/gloubin ratio at $1^{\text {st }}$ week. Those percentages were decreased to $55 \%$ and 
$50 \%$ respectively at $2^{\text {nd }}$ week. At $3^{\text {rd }}$ week those percentage also were $50 \%$ and $50 \%$ of both conventional and polythene gloves groups respectively.

Table (4) showed relationship between studied patients in both conventional occlusive dressing and polythene gloves dressing technique groups according to burn wound morphology and signs of infection per weeks.

Regarding the wound morphology, (reepitheliazation) occurred in $40 \%$ and $60 \%$ of patients in conventional occlusive dressing and polythene gloves groups at $1^{\text {st }}$ week post burn. These percentages increased to $85 \%$ of patients managed by the conventional occlusive dressing in conventional group and in $100 \%$ of patients managed by the polythene gloves dressing at $2^{\text {nd }}$ week post burn.

Concerning granulation, it occurred in $40 \%$ and $53 \%$ of patient in both conventional occlusive dressing and polythene gloves groups at $1^{\text {st }}$ week post burn and then these percentages increased to $100 \%$ of both groups. No significant differences were existed between the two groups regarding wound morphology.

This table also illustrates that tenderness and erythema represented in equal percentage $25 \%$ of patients in conventional occlusive dressing at $1^{\text {st }}$ week. These percentages decreased to $15 \%, 10 \%$ respectively at $2^{\text {nd }}$ week. While in patients managed with polythene gloves represented $15 \%$, and $10 \%$ respectively at $1^{\text {st }}$ week. These decreased to equal percentages $10 \%$ at $2^{\text {nd }}$ week. No statistical significant was found between the both the conventional occlusive dressing and polythene gloves groups regarding signs of infection at $1^{\text {st }}, 2^{\text {nd }}$ and $3^{\text {rd }}$ week.

Table (5) showed relationship between the studied patients in both conventional occlusive dressing technique and polythene gloves dressing technique according to bacteriological culture results on (4th, 11th, 18th day).
This table shows the relation of bacteriological wound culture results in relation to the two lines of treatment. The results of the $1^{\text {st }}$ culture showed that $40 \%$ of the wound treated by conventional occlusive dressing were sterile, while $45 \%$ of the wound treated by polythene gloves were sterile.

It can be seen that the results of the $2^{\text {nd }}$ culture indicated that $50 \%$ and $55 \%$ of the wound managed by conventional occlusive technique and polythene gloves were sterile culture respectively. Those percentages were increased to $66.7 \%$ and $60 \%$ respectively in third culture. No significant relation was found between the two dressing techniques and the $1^{\text {st }}, 2^{\text {nd }}$ and $3^{\text {rd }}$ culture.

Table (6) showed relationship between the studied patients in both the conventional occlusive dressing technique and polythene gloves dressing technique according to bacteriological species isolated from patients' hand on (4th, 11th, 18th day).

As regards presence or absent of microorganisms, the result of $1^{\text {st }}$ culture on $4^{\text {th }}$ day post burn indicates that, staph aureus isolated from $35 \%$ and $40 \%$ in wound managed by both conventional occlusive dressing technique and polythene gloves dressing technique respectively. These results decreased to $25 \%$ and $10 \%$ respectively in the $3^{\text {rd }}$ culture Regarding conventional dressing technique pseudomonas and klebsiella isolated from only $5 \%$. In polythene glove technique Ecoli isolated from $5 \%$.

The $2^{\text {nd }}$ culture on $11^{\text {th }}$ day post burn showed that staph aurous isolated from wound managed by conventional occlusive dressing technique and polythene gloves dressing technique was decreased to $30 \%$ and $25 \%$ respectively; were as staphylococcus, E-coli and staphylococcus + E-coli isolated from an equal percentages (5\%) of conventional dressing technique, while E-coli isolated from $5 \%$ of polythene gloves dressing technique. 
The $3^{\text {rd }}$ culture on $18^{\text {th }}$ day post burn also revealed staph aurous was decreased to $20 \%$ and $10 \%$ respectively in both conventional occlusive dressing technique and polythene gloves dressing technique respectively, while staph aureus + staphylococcus isolated from $8.3 \%$ of conventional dressing technique and $10 \%$ of polythene gloves dressing technique.

Table (7) showed relationship between the studied patients in both the conventional occlusive and polythene gloves dressing techniques per week and wound pain.

This table showed the relation between the two dressing techniques and perception of pain. Pain during the conventional occlusive dressing was experienced by $100 \%, 80 \%$ and $75 \%$ of the patients respectively during the $1^{\text {st }}, 2^{\text {nd }}$, and $3^{\text {rd }}$ week. On the other hand pain was not experienced by $75 \%, 100 \%$ and $100 \%$ respectively in the patients managed by the polythene gloves during the $1^{\text {st }}, 2^{\text {nd }}$, and $3^{\text {rd }}$ week. A statistical significance was found between two dressing techniques and wound pain ( $\mathrm{p}<0.001,<0.001,=0.048)$.

Table (8) showed relationship between the studied patients in both conventional occlusive and polythene gloves dressing techniques regarding cost of dressing and time consumed until complete healing.

This table showed that conventional occlusive dressing represented the highest cost of dressing, mean was (715.65 LE) and the mean of time consumed was (5.07 hours) until complete healing. While, polythene gloves dressing represented the lowest cost of dressing, mean was (508.93 LE) and the mean time consumed was (2.49 hours) until complete healing.

Table (9) showed relationship between the studied patients in both the conventional occlusive dressing technique and polythene gloves dressing technique regarding DLAs. As regards dressing gown the results indicated that $75 \%, 30 \%$ of patient in the conventional occlusive dressing and polythene gloves dressing groups are unable to dress gown on $5^{\text {th }}$ day post burn while, $45 \%$ and $75 \%$ of both conventional occlusive dressing and polythene gloves dressing groups can dress gown with difficulty, on 9th day post burn. These percentages decreases to $(25 \%, 25 \%$ and $0.0 \%$ ) in patient managed by conventional dressing techniques and $(20 \%, 10 \%$ and $0.0 \%$ ) of polythene gloves technique on $13^{\text {th }}, 17^{\text {th }}$ and $21^{\text {st }}$ days post burn. There was a statistical significance differences between dressing and burned hand patients groups $(\mathrm{p}=0.006,0.014)$ on 5 th and 9 th day post burn respectively.

In addition this table illustrated that on 9th day post burn (25\% and $75 \%)$ of patient managed with conventional occlusive dressing and polythene gloves dressing groups are able to turning on/off taps, these percentages increased to equal percentage $(100 \%)$ of both conventional dressing and polythene gloves techniques on 21 st day post burn. A statistical significance was found between both groups regarding turning on/off taps on 5th, 9th and 13th day post burn $(\mathrm{p}=0.001,0.006,0.012)$ respectively. Regarding brush teeth, it can be done adequately in $(10 \%, 25 \%, 45 \%$, $75 \%$ and $100 \%$ ) of conventional dressing during the five observations (5th, 9th, 13th, 17th, 21st days post burn). While brushing teeth can be done adequately in $35 \%, 60 \%$, $90 \%, 90 \%, 100 \%$ of the polythene gloves dressing on the $5^{\text {th }}, 9$ th $, 13^{\text {th }}, 17^{\text {th }}, 21^{\text {st }}$ days post burn respectively. A statistical significance differences were found between burned hand patients in both groups and brush teeth $(\mathrm{p}=0.021,0.004$, 0.008 ) during the first three observations; for the favour of polythene glove dressing technique.

For cutting bread, the results revealed that $15 \%$ of patient in conventional dressing group can cut bread whereas 55\% of polythene gloves group can do that on 5th day post burn. A statistical significance was existed between both groups $(p=0.019$, 0.030) during the first two observations (5th and 9th day post burn) respectively. It can 
also be seen that use spoon can be done adequately in the same percentage $(20 \%)$ of patient in conventional dressing group at 5 th and 9th days, and then increased to 55\%, $75 \%$ and $100 \%$ on 13 th, 17 th and 21 st days post burn. In polythene gloves group use spoonful can be done adequately in and $35 \%, 35 \%, 90 \%, 90 \%$ and $100 \%$ on 5 th, 9th, 13th, 17th and $21^{\text {st }}$ days post burn respectively. There was a statistical significance between burned hand patients in both groups and use spoonful $(\mathrm{p}=0.009$, $0.030,0.035$ ) on 5 th, 9 th and 13 th days post burn; for the favour of polythene glove dressing technique.

Related to moving heavy cans, (15\%, and $25 \%$ ) of conventional dressing group respectively were able to do that adequately on $5^{\text {th }}$ and $9^{\text {th }}$ day post burn. While $55 \%$ and $80 \%$ of patients in polythene gloves dressing group can move heavy cans adequately on 5th and 9th day post burn respectively. There was a statistical significance difference between burned hand patients groups and moving heavy cans on $5^{\text {th }}$ and $9^{\text {th }}$ day post burn $(\mathrm{p}=0.008$, $0.001)$.

Among conventional dressing group, putting in /out the electrical plugs not be done in $50 \%$ on $5^{\text {th }}$ day post burn then decreased to $20 \%$ on $9^{\text {th }}$ day post burn. On the other hand $60 \%$ and $85 \%$ of patients were able to put in/out the electrical plugs adequately on $5^{\text {th }}$ and $9^{\text {th }}$ day post burn respectively in polythene gloves dressing group. Statistical significance were existed between burned hand patients groups regarding putting in/out the electrical plugs $(\mathrm{p}=0.001,<0.001)$ on 5 th, and 9th day post burn; for the favour of polythene glove dressing technique.

In relation to turning pages, $55 \%, 30 \%$ and $5 \%$ of patients on the conventional dressing group were unable to do that on the $5^{\text {th }}, 9^{\text {th }}$ and $13^{\text {th }}$ days post burn. While $25 \%$ of patients managed by polythene gloves dressing could turn pages on 5 th day post burn, then increased to $30 \%$ and $95 \%$ on 9 th and 13th day post burn. These percentages increased to equal percentages $(100 \%)$ on $21^{\text {st }}$ days post burn for patients in both conventional dressing and polythene gloves groups. Statistical significance differences were found between burned hand patients groups in relation to turning pages $(\mathrm{p}=0.001,0.35,0.019)$ on $5^{\text {th }}, 9^{\text {th }}$ and $13^{\text {th }}$ days post burn; for the favour of polythene glove dressing technique.

\section{Discussion}

The treatment of burned hands can be time consuming and the patient rendered helpless by the dressing, particularly if both hands are involved. The aim of wound care in burns is to: maintain a clean moist environment, promote patient comfort, offer protection from infection or further trauma and facilitate optimal activity and function. Proper wound care is necessary to promote healing that result in an intact skin layer ${ }^{(33)}$. There are many techniques are available for the treatment of partial thickness hand burns. All treatment full under the heading of either: exposure (open) treatment or occlusive (closed) treatment. Exposure treatment is simple but increase the risk of infection, which healed wound healing. Occlusive dressing, once applied hindering hand finger motion ${ }^{(30)}$.

The present study was conducted in order to evaluate the effect of conventional occlusive dressing versus polythene gloving on second degree burned hands.

In the present study the majority of the subject's betwen18-25 years. This finding in line with Garrison (2002) who mentioned that the most common age groups injured are age 17 to 25 years old ${ }^{(34)}$. In addition; Elmelegy (2006) mentioned that the patients between 15 and 30 years were frequently affected more than other age group ${ }^{(35)}$. Furthermore Smeltzer and Bare (2004) emphasized that young children and elderly people are at particularly high risk for burn injury $^{(30)}$.

As regards sex, the present study showed that, the majority of subjects were 
males. On the contrary study done by Abdelrahaman (2008) at Alexandria main university hospital found that the majority of subjects were females. This would be attributed to that Egyptian females are responsible for all domestic activities which may expose them to many sources of fire. Moreover they tend to wear clothes that are of synthetic materials ${ }^{(36)}$.

The findings of this study also revealed that the majority of subjects were read and write only and workers. This observation may be leading to the opinion that the subject in the present study had lack of knowledge about prevention of burn and lack of occupational safety. It was noticed that the most of subjects in the studied groups were working as chief, waiter and baker. Their jobs put them in risks. This is in line with Smeltzer and Bare (2004) who mentioned that burns can occur from workrelated injuries ${ }^{(30)}$.

Also the finding of this study indicated that the majority of subjects were affected by flame burn, similar finding was revealed by studies done by Abd-elrahaman (2008) who concluded that that accidents can occur, through carelessness or unsafe working practices in those who use heat ${ }^{(36)}$. Moreover, regards to BMI the most of subjects in both conventional and polythene groups have normal body mass index and less than the half were overweight. The study was done by Khalil (2008) on exposure method versus conventional dressing for patient with abdominal surgery founded that percentage of patients has normal BMI was $44.4 \%$, while $11.1 \%$ were overweight. Also she founded that there was no statistical significant between the infected and not infected in relation to $\mathrm{BMI}^{(37)}$.

Concerning laboratory investigations among subjects of conventional occlusive and polythene gloves groups, the percentage of normal values for hemoglobin, hemotacrit, total proteins, serum albumin and albumin/globin ratio were in both group decreased. In spite of this result healing process took place. This may be due to reinforcement of patients of both groups to compliance to the instruction given to double the recommended diet. The study done by Nour (2003) on the effect of nutritional regimen for moderate burn patients on graft take at the burn unit of Alexandria Main University revealed that, the mean values of hemoglobin, hematocrit, and serum albumin in both control and experimental groups were decreased, but albumin/globin ratio was increased in experimental group ${ }^{(1)}$.

Regarding WBCs the normal value was improved in both conventional occlusive and polythene gloves groups. This indicated that wound only colonized by bacterial and the number of microorganisms which was present not produced infection. This was supported by Potter and Perry (1999) who mentioned that the wound considers colonized when it contains bacteria but not causing host reactions ${ }^{(38)}$.

As regards the morphology of wound in conventional occlusive and polythene gloves groups the results revealed that reepithelialization occurred in nearly two third and all of patients who managed by polythene gloves at $1^{\text {st }}$ and $2^{\text {nd }}$ week post burn respectively. This finding supported by study done on effectiveness of two dressing techniques on the healing of recent moderately burn in burns unit of Tanta hospitals by Ragab (2002) pointed that wounds heal more quickly in warm moist environment $^{(39)}$. In addition El-Shatby (2003) compared between two dressing techniques on wound healing found that warm moist environment accelerated wound healing, this study was done on patients with grade I diabetic foot ulcer ${ }^{(40)}$.

Concerning granulation tissue process it was observed more than third of patient in the conventional group and more than half of the polythene glove had start granulation. Regarding re-epithelialization, occurred in both conventional occlusive and polythene gloves groups the result revealed that in more half of the studied patient managed by 
polythene gloving technique in the $1^{\text {st }}$ week and all of them in the $2^{\text {nd }}$ week. However this difference was present, but it was not significant for both groups regarding reepithelialization and granulation. This result may be due to using silver-sulphadizine in both groups, which is a solution based so it prevents dryness of wound surface ${ }^{(41)}$. In addition debridement of wound was done for both studied groups till all dead tissue removed and granulation tissue started to appear. Debridement of nonviable tissue is the most important factor in wound management. Wound healing can't take place until necrotic tissue is removed ${ }^{(42)}$. This was supported by Edmond (2001) who showed that debridement of devitalized tissue from the wound lead to more rapid healing ${ }^{(43)}$.

The burned hand wound bacteriological cultures results revealed that no statistical significance differences were found between the two groups at $4^{\text {th }}$ day post burn. Bacteriological culture results in $4^{\text {th }}$ day post burn were positive in approximately half of the sample of both conventional and polythene gloving groups. This could be explained by auto contamination from unburned skin and contamination during transportation. This in line with the study on the adult burn patient: identification of nursing diagnosis by Abdel-Dayem et al (1992) who reported that the incidence of infection was $50 \%$ after $3^{\text {rd }}$ days post burn ${ }^{(44)}$.

Moreover, in second cultures of wound, the study revealed that sterile culture was approximately half of the sample in both conventional and polythene gloving groups. These percentages increased to two third of the conventional and polythene gloving groups at $3^{\text {rd }}$ culture. These results were due to frequent debridement. Also precautions are strictly carried out by the attending nurses for patients treated with conventional occlusive dressing and researcher for patients treated with polythene gloving techniques during the management of the patients. the management comprises not only adherence to aseptic technique during the care of the wound but protection from sources of contamination including other patient, staff members, visitors and equipments of dressing. Furthermore, using of sliver sulfadiazine as a topical antibiotic.

In spite of following aseptic techniques in polythene gloving, the infection rate with pseudomonas still high. This may be supported by Smeltzer and Bare (2004) who pointed out that despite aseptic precautions and the use of topical antimicrobial agents the burn wound is an excellent medium for bacterial growth and proliferation. There is general agreement that some of antibacterial therapy applied to the wound is the best method of local care in extensive burn injury. Topical antibacterial therapy doesn't sterilize the burn wound; it simply reduces the number of bacteria so that the overall microbial population can be controlled by body's host defense mechanism ${ }^{(30)}$.

The findings also revealed that there were statistical significance differences between the two dressing techniques in relation to pain during dressing change. The results revealed that conventional occlusive dressing was more painful than polythene gloves dressing; this is supported by study done by Ragab (2002) ${ }^{(39)}$. This may be explained as the gloves were not adhering to wound surface so its removal was easy and painless. Also dressing with gloves took less time than conventional dressing, which decreased time exposed to air. Moreover, explanation to the patients during dressing change which decreased patient anxiety and decreased pain. This is in line with Smeltzer and Bare (2004) who mentioned that nerve endings are partially intact in second degree burns, with long time exposing to air resulting in significant pain in addition to the constant background pain caused by the burn injury itself ${ }^{(41)}$.

Moreover in the present study the total cost of dressing with conventional occlusive dressing was more expensive than polythene gloves. This finding was in line 
with Khalil (2008) who found that conventional dressing was expensive ${ }^{(37)}$.

Furthermore the results revealed that time consumed in polythene gloves was less than conventional occlusive dressing. This result was in line with O'shea and Porter (2005) who mentioned that occlusive dressings were complex. Easy application and removal should be a guide in selecting the dressing material to be used ${ }^{(8)}$. This result may be due to the time consumed in exercise regimen which followed before conventional dressing, the fingers should be wrapped individually to promote adequate healing and functional body alignment positions were maintained by using splints or by careful positioning of the patient.

Regarding DLAs the present results revealed that there were statistical significance differences between the conventional occlusive and polythene gloves technique groups at the first two observations $\left(5^{\text {th }}\right.$ and $9^{\text {th }}$ post burn) in relation to dressing gown, cutting bread, moving heavy cans and putting in/out electric plugs. Statistical significance were found between the conventional occlusive and polythene gloves groups during the first three observations $\left(5^{\text {th }}, 9\right.$ th and $13^{\text {th }}$ days post burn) in turning on/off taps, brush teeth, use spoonful and turnings pages. This may be due to gloves provided free movement of fingers, frequent exercise which maintained joint integrity and mobility. Patient can perform as many selfcare tasks as possible will also help the patient develop independence and self esteem. Independency enhances a person's health status and emotional well-being. This result is in line with Ferguson and Fodden (2000) who mentioned that glove encourages active mobilization of the fingers from the earliest possible time ${ }^{(45)}$.

Elmelegy (2006) in a study about the effect of physical rehabilitative therapy in minimizing contracture deformity of the burned hand at Tanta university revealed that approximately two third of experimental and control group which received conventional dressing were independent in brushing teeth respectively while, minority of experimental and control group were independent in cutting meat after wound healing ${ }^{(35)}$.

\section{Conclusion}

The results of this study found no statistically significant difference between conventional occlusive and polythene gloving techniques regarding the time of healing and infection rate. For pain, time consumed, cost and daily living activities the study results indicated that polythene gloving was painless, less time consuming, low cost and allowing for daily living activities as compared with conventional occlusive technique.

\section{Recommendations}

Based on the findings of the present study, the following recommendations are derived and suggested:

- Using polythene gloves for burn wound management at burn unit should be emphasized.

- In-service training programs for nurses' about polythene gloving techniques.

- Studies effect of polythene gloves dressing on second degree burned hands/hand at outpatient and on $3^{\text {rd }}$ degree burned hand. 
Table (1): Distribution of studied patients in both conventional occlusive dressing and polythene gloving dressing according to their biosociodemographic variables upon admission

\begin{tabular}{|c|c|c|c|c|}
\hline \multirow[t]{2}{*}{ Variables } & \multicolumn{2}{|c|}{$\begin{array}{c}\text { Conventional } \\
\text { dressing } \\
(\text { no }=\mathbf{2 0}) \\
\end{array}$} & \multicolumn{2}{|c|}{$\begin{array}{l}\text { Polythene gloves } \\
\text { dressing } \\
(\text { no }=20)\end{array}$} \\
\hline & No & $\%$ & No & $\%$ \\
\hline Sex & & & & \\
\hline Male & 12 & 60.0 & 15 & 75.0 \\
\hline Female & 8 & 40.0 & 5 & 25.0 \\
\hline Total & 20 & 100 & 20 & 100 \\
\hline Age & & & & \\
\hline $18-25$ & 12 & 60.0 & 10 & 50.0 \\
\hline $26-35$ & 8 & 40.0 & 10 & 50.0 \\
\hline Total & 20 & 100 & 20 & 100 \\
\hline Education & & & & \\
\hline 1- Illiterate & 10 & 50.0 & 6 & 30.0 \\
\hline 2- Read \& Write & 5 & 25.0 & 9 & 45.0 \\
\hline 3- Diploma & 5 & 25.0 & 5 & 25.0 \\
\hline 4- Bachelor degree & 0 & 0.0 & 0 & 0.0 \\
\hline Total & 20 & 100 & 20 & 100 \\
\hline Occupation & & & & \\
\hline 1- Manual & 14 & 70.0 & 16 & 80.0 \\
\hline 2-Cleric & 0 & 0.0 & 0 & 0.0 \\
\hline 3- No Work & 6 & 30.0 & 4 & 20.0 \\
\hline Total & 20 & 100 & 20 & 100 \\
\hline
\end{tabular}


Table (2): Distribution of the studied patients in both conventional occlusive dressing and polythene gloves groups in relation to cause of burn, current medication received and body mass index

\begin{tabular}{|c|c|c|c|c|}
\hline \multirow[t]{2}{*}{ Variables } & \multicolumn{2}{|c|}{$\begin{array}{c}\text { Conventional } \\
\text { dressing } \\
(\text { no }=20)\end{array}$} & \multicolumn{2}{|c|}{$\begin{array}{l}\text { Polythene gloves } \\
\text { dressing } \\
(\text { no }=20)\end{array}$} \\
\hline & No & $\%$ & No & $\%$ \\
\hline \multicolumn{5}{|l|}{ Cause } \\
\hline 1- Flame & 17 & 85.0 & 18 & 90.0 \\
\hline 2- Scalds & 3 & 15.0 & 2 & 10.0 \\
\hline Total & 20 & 100 & 20 & 100 \\
\hline \multicolumn{5}{|l|}{ Medication } \\
\hline 1- Corticosteroids & 17 & 85.0 & 19 & 95.0 \\
\hline 2- Anti-inflammatory & 20 & 100.0 & 20 & 100.0 \\
\hline 3- Antibiotics & 20 & 100.0 & 20 & 100.0 \\
\hline Total & 20 & 100 & 20 & 100 \\
\hline \multicolumn{5}{|l|}{ Body mass index $(\mathrm{kg} / \mathrm{m} 2)$} \\
\hline 1- Normal (18.5 - 24.9) & 11 & 55.0 & 12 & 60.0 \\
\hline 2- Overweight ( $\uparrow 24.9)$ & 9 & 45.0 & 8 & 40.0 \\
\hline 3- Underweight ( $\downarrow$ 18.5) & 0 & 0.0 & 0 & 0.0 \\
\hline Total & 20 & 100 & 20 & 100 \\
\hline $\begin{array}{l}\text { Total body surface area } \\
\text { (TBSA): }\end{array}$ & \multicolumn{2}{|c|}{$19.25 \pm 3.86$} & \multicolumn{2}{|c|}{$19.30 \pm 3.87$} \\
\hline
\end{tabular}


Conventional Occlusive Dressing versus Polythene Gloving on Burned Hands

Table (3): Distribution of studied patients in both conventional occlusive dressing and polythene gloves groups according to laboratory investigations at 1st, 2nd and 3rd week

\begin{tabular}{|c|c|c|c|c|c|c|c|c|c|c|c|c|}
\hline \multirow{3}{*}{ Lab. Investigation } & \multicolumn{4}{|c|}{$1^{\text {st }}$ Week } & \multicolumn{4}{|c|}{$2^{\text {nd }}$ Week } & \multicolumn{4}{|c|}{$3^{\text {rd }}$ Week } \\
\hline & \multicolumn{2}{|c|}{$\begin{array}{l}\text { Conventional } \\
\text { dressing } \\
(\mathrm{n} 0=20)\end{array}$} & \multicolumn{2}{|c|}{$\begin{array}{l}\text { Polythene } \\
\text { gloves } \\
(\mathrm{n} 0=20) \\
\end{array}$} & \multicolumn{2}{|c|}{$\begin{array}{l}\text { Conventional } \\
\text { dressing } \\
(\text { no=20) }\end{array}$} & \multicolumn{2}{|c|}{$\begin{array}{c}\text { Polythene } \\
\text { gloves } \\
(\text { no=20) }\end{array}$} & \multicolumn{2}{|c|}{$\begin{array}{l}\text { Conventional } \\
\text { dressing } \\
(\text { no=4)\# }\end{array}$} & \multicolumn{2}{|c|}{$\begin{array}{c}\text { Polythene } \\
\text { gloves } \\
\left(\mathrm{n}_{0}=2\right) \#\end{array}$} \\
\hline & No. & $\%$ & No. & $\%$ & No. & $\%$ & No. & $\%$ & No. & $\%$ & No. & $\%$ \\
\hline $\begin{array}{l}\text { 1- Hb } \\
\text { Normal } \\
\text { M: 13.8-17.2 g/dl } \\
\text { F: } 12.1-15.1 \mathrm{~g} / \mathrm{dl} \\
\text { Abnormal }\end{array}$ & 17 & $\begin{array}{r}85.0 \\
15.0 \\
\end{array}$ & 18 & $\begin{array}{l}90.0 \\
10.0\end{array}$ & 15 & 25.0 & 4 & 20.0 & 1 & $\begin{array}{r}75.0 \\
25.0 \\
\end{array}$ & 1 & $\begin{array}{l}50.0 \\
50.0 \\
\end{array}$ \\
\hline \begin{tabular}{|l} 
2-Hct \\
Normal \\
M: 40.7- 50.3\% \\
F: 36.1- $44.4 \%$ \\
Abnormal
\end{tabular} & 18 & 90.0 & 19 & 95.0 & 15 & 75.0 & 17 & 85.0 & 3 & 75.0 & 1 & 50.0 \\
\hline \begin{tabular}{|l|} 
3- Wbcs \\
Normal (3.8 - $9.8 \times 10^{3} /$ Micro \\
liters) \\
Abnormal
\end{tabular} & $\begin{array}{c}4 \\
16\end{array}$ & $\begin{array}{l}20.0 \\
80.0\end{array}$ & $\begin{array}{c}1 \\
19\end{array}$ & $\begin{array}{r}5.0 \\
95.0\end{array}$ & $\begin{array}{c}7 \\
13\end{array}$ & $\begin{array}{l}35.0 \\
65.0\end{array}$ & 7 & $\begin{array}{l}35.0 \\
65.0\end{array}$ & 3 & $\begin{array}{r}75.0 \\
25.0\end{array}$ & 0 & $\begin{array}{l}100.0 \\
00.0\end{array}$ \\
\hline $\begin{array}{l}\text { 4- S. Albumin } \\
\text { Normal }(3.6-5.0 \mathrm{~g} / \mathrm{dl}) \\
\text { Abnormal }\end{array}$ & $\begin{array}{c}12 \\
8\end{array}$ & $\begin{array}{l}60.0 \\
40.0\end{array}$ & $\begin{array}{c}17 \\
3\end{array}$ & $\begin{array}{l}85.0 \\
15.0\end{array}$ & $\begin{array}{c}11 \\
9\end{array}$ & $\begin{array}{l}55.0 \\
45.0\end{array}$ & $\begin{array}{c}12 \\
8\end{array}$ & $\begin{array}{l}60.0 \\
40.0\end{array}$ & $\begin{array}{l}2 \\
2\end{array}$ & $\begin{array}{l}50.0 \\
50.0\end{array}$ & $\begin{array}{l}1 \\
1\end{array}$ & $\begin{array}{l}50.0 \\
50.0\end{array}$ \\
\hline $\begin{array}{l}\text { 5- Total protein } \\
\text { Normal }(6.5-8.5 \mathrm{~g} / \mathrm{dl}) \\
\text { Abnormal }\end{array}$ & $\begin{array}{c}14 \\
6\end{array}$ & $\begin{array}{l}70.0 \\
30.0\end{array}$ & $\begin{array}{c}14 \\
6\end{array}$ & $\begin{array}{l}70.0 \\
30.0\end{array}$ & $\begin{array}{c}7 \\
13\end{array}$ & $\begin{array}{l}35.0 \\
65.0\end{array}$ & $\begin{array}{c}11 \\
9\end{array}$ & $\begin{array}{l}55.0 \\
45.0\end{array}$ & $\begin{array}{l}2 \\
2\end{array}$ & $\begin{array}{l}50.0 \\
50.0\end{array}$ & $\begin{array}{l}1 \\
1\end{array}$ & $\begin{array}{l}50.0 \\
50.0\end{array}$ \\
\hline $\begin{array}{l}\text { 6-Albumin/globin R } \\
\text { Normal }(1.5-2.5) \\
\text { Abnormal }\end{array}$ & $\begin{array}{c}12 \\
8\end{array}$ & $\begin{array}{l}60.0 \\
40.0\end{array}$ & $\begin{array}{c}16 \\
4\end{array}$ & $\begin{array}{l}80.0 \\
20.0\end{array}$ & $\begin{array}{c}11 \\
9\end{array}$ & $\begin{array}{l}55.0 \\
45.0\end{array}$ & $\begin{array}{l}10 \\
10\end{array}$ & $\begin{array}{l}50.0 \\
50.0\end{array}$ & $\begin{array}{l}2 \\
2\end{array}$ & $\begin{array}{l}50.0 \\
50.0\end{array}$ & $\begin{array}{l}1 \\
1\end{array}$ & $\begin{array}{l}50.0 \\
50.0\end{array}$ \\
\hline
\end{tabular}


Conventional Occlusive Dressing versus Polythene Gloving on Burned Hands

Table (4): Relationship between studied patients in both conventional occlusive dressing and polythene gloves groups according to burn wound morphology and signs of infection per weeks

\begin{tabular}{|c|c|c|c|c|c|c|c|c|c|c|c|c|}
\hline \multirow{3}{*}{ Burn wound assessment } & \multicolumn{4}{|c|}{$1^{\text {st }}$ Week } & \multicolumn{4}{|c|}{$2^{\text {nd }}$ Week } & \multicolumn{4}{|c|}{$3^{\text {rd }}$ Week } \\
\hline & \multicolumn{2}{|c|}{$\begin{array}{c}\text { Conventional } \\
\text { dressing } \\
(\mathrm{n}=20)\end{array}$} & \multicolumn{2}{|c|}{$\begin{array}{l}\text { Polythene } \\
\text { gloves } \\
(\mathrm{n}=20)\end{array}$} & \multicolumn{2}{|c|}{$\begin{array}{c}\text { Conventional } \\
\text { dressing } \\
(\mathrm{n}=20)\end{array}$} & \multicolumn{2}{|c|}{$\begin{array}{l}\text { Polythene } \\
\text { gloves } \\
(\mathrm{n}=20)\end{array}$} & \multicolumn{2}{|c|}{$\begin{array}{c}\text { Conventional } \\
\text { dressing } \\
(\mathrm{n}=4) \#\end{array}$} & \multicolumn{2}{|c|}{$\begin{array}{c}\text { Polythene } \\
\text { gloves } \\
(\mathrm{n}=2) \#\end{array}$} \\
\hline & No. & $\%$ & No. & $\%$ & No. & $\%$ & No. & $\%$ & No. & $\%$ & No. & $\%$ \\
\hline $\begin{array}{l}\text { Appearance of wound } \\
\text { Re-epithelialization }\end{array}$ & 8 & 40.0 & 12 & 60.0 & 17 & 85.0 & 20 & 100.0 & 4 & 100.0 & 2 & 100.0 \\
\hline$\chi^{2}(\mathrm{p})$ & \multicolumn{4}{|c|}{$1.758(0.185)$} & \multicolumn{4}{|c|}{$3.243(0.072)$} & \\
\hline Granulation & 0 & 00.0 & 0 & 00.0 & 8 & 40.0 & 11 & 55.0 & 4 & 100.0 & 2 & 100.0 \\
\hline$\chi^{2}(\mathrm{p})$ & \multicolumn{4}{|c|}{-} & \multicolumn{4}{|c|}{$1.600(0.206)$} & \\
\hline $\begin{array}{l}\text { Signs of infection } \\
\text { Tenderness }\end{array}$ & 5 & 25.0 & 3 & 15.0 & 2 & 10.0 & 1 & 5.0 & 0 & 0.0 & 0 & 0.0 \\
\hline Erythema & 5 & 25.0 & 2 & 10.0 & 2 & 10.0 & 1 & 5.0 & 0 & 0.0 & 0 & 0.0 \\
\hline Purulent exudates & 0 & 0.0 & 0 & 0.0 & 0 & 0.0 & 0 & 0.0 & 0 & 0.0 & 0 & 0.0 \\
\hline Conversion of $2^{\text {nd }}$ degree to 3 & 0 & 0.0 & 0 & 0.0 & 0 & 0.0 & 0 & 0.0 & 0 & 0.0 & 0 & 0.0 \\
\hline Brown or black discoloration & 0 & 0.0 & 0 & 0.0 & 0 & 0.0 & 0 & 0.0 & 0 & 0.0 & 0 & 0.0 \\
\hline MCp & \multicolumn{4}{|c|}{1.000} & & \\
\hline
\end{tabular}

$\chi^{2}$ : Chi square test

MCp: p for Monte Carlo test

*: Statistically significant at $p \leq 0.05$

\#the remaining numbers of patients in each type of technique was discharged in the $3^{\text {rd }}$ week. 
Table (5): Relationship between studied patients in both the conventional occlusive dressing technique and polythene gloves dressing technique according to bacteriological culture results on $\left(4^{\text {th }}, 11^{\text {th }}, 18^{\text {th }}\right.$ day)

\begin{tabular}{|c|c|c|c|c|}
\hline \multirow[t]{2}{*}{ Bacterial wound culture } & \multicolumn{2}{|c|}{$\begin{array}{c}\text { Conventional dressing } \\
\text { technique }\end{array}$} & \multicolumn{2}{|c|}{$\begin{array}{c}\text { Polythene gloves dressing } \\
\text { technique }\end{array}$} \\
\hline & No & $\%$ & No & $\%$ \\
\hline $1^{\text {st }}$ culture $\left(4^{\text {th }}\right.$ day post burn $)$ & & & & \\
\hline Positive & 12 & 60.0 & 11 & 55.0 \\
\hline Sterile & 8 & 40.0 & 9 & 45.0 \\
\hline Total & 20 & 100.0 & 20 & 100.0 \\
\hline$\chi^{2}(\mathbf{p})$ & \multicolumn{4}{|c|}{$0.102(0.749)$} \\
\hline $2^{\text {nd }}$ culture $\left(11^{\text {th }}\right.$ day post burn $)$ & & & & \\
\hline Positive & 10 & 50.0 & 9 & 45.0 \\
\hline Sterile & 10 & 50.0 & 11 & 55.0 \\
\hline Total & 20 & 100.0 & 20 & 100.0 \\
\hline$\chi^{2}(\mathbf{p})$ & \multicolumn{4}{|c|}{$0.100(0.752)$} \\
\hline $3^{\text {rd }}$ culture $\left(18^{\text {th }}\right.$ day post burn $) \#$ & & & & \\
\hline Positive & 4 & 33.3 & 3 & 30.0 \\
\hline Sterile & 8 & 66.7 & 7 & 70.0 \\
\hline Total & 12 & 100.0 & 10 & 100.0 \\
\hline FEp & \multicolumn{4}{|c|}{1.000} \\
\hline
\end{tabular}

$\chi^{2}$ : Chi-square test

FEp: $p$ value for Fisher Exact test

*: Statistically significant at $\mathrm{p} \leq 0.05$

\# the remaining numbers of patients in each type of technique was discharged in the $3^{\text {rd }}$ week. 
Table (6): Relationship between studied patients in both the conventional occlusive dressing technique and polythene gloves dressing technique according to bacteriological species isolated from patients' hand on $\left(4^{\text {th }}, 11^{\text {th }}, 18^{\text {th }}\right.$ day $)$

\begin{tabular}{|c|c|c|c|c|c|c|c|c|c|c|c|c|}
\hline \multirow{3}{*}{ *Microorganism } & \multicolumn{4}{|c|}{$\begin{array}{c}1^{\text {st }} \text { culture } \\
\left(4^{\text {th }} \text { day post burn }\right)\end{array}$} & \multicolumn{4}{|c|}{$\begin{array}{c}2^{\text {nd }} \text { culture } \\
\left(11^{\text {th }} \text { day post burn }\right)\end{array}$} & \multicolumn{4}{|c|}{$\begin{array}{c}3^{\text {rd }} \text { culture } \\
\left(18^{\text {th }} \text { day post burn }\right)\end{array}$} \\
\hline & \multicolumn{2}{|c|}{$\begin{array}{c}\text { Conventional } \\
\text { technique } \\
\left(\mathrm{n}_{0}=12\right)\end{array}$} & \multicolumn{2}{|c|}{$\begin{array}{l}\text { Polythene } \\
\text { gloves } \\
\text { Technique } \\
\text { (no=11) }\end{array}$} & \multicolumn{2}{|c|}{$\begin{array}{c}\text { Conventional } \\
\text { technique } \\
(\mathrm{n} 0=10)\end{array}$} & \multicolumn{2}{|c|}{$\begin{array}{l}\text { Polythene } \\
\text { gloves } \\
\text { technique } \\
\text { (no=9) }\end{array}$} & \multicolumn{2}{|c|}{$\begin{array}{c}\text { Conventional } \\
\text { technique } \\
(\mathrm{n} 0=4) \#\end{array}$} & \multicolumn{2}{|c|}{$\begin{array}{c}\text { Polythene } \\
\text { gloves } \\
\text { technique } \\
(\mathrm{n} 0=3) \#\end{array}$} \\
\hline & No. & $\%$ & No. & $\%$ & No. & $\%$ & No. & $\%$ & No. & $\%$ & No. & $\%$ \\
\hline Staph. aureus & 7 & 35.0 & 8 & 40.0 & 6 & 30.0 & 5 & 25.0 & 3 & 25.0 & 1 & 10.0 \\
\hline Pseudomonas & 1 & 5.0 & 0 & 0.0 & 2 & 10 & 1 & 5.0 & 0 & 0.0 & 1 & 10.0 \\
\hline Streptococcus & 3 & 15.0 & 2 & 10.0 & 1 & 5.0 & 2 & 10.0 & 0 & 0.0 & 0 & 0.0 \\
\hline Klebsilla & 1 & 5.0 & 0 & 0.0 & 0 & 0.0 & 0 & 0.0 & 0 & 0.0 & 0 & 0.0 \\
\hline E-coli & 0 & 0.0 & 1 & 5.0 & 0 & 0.0 & 1 & 5.0 & 0 & 0.0 & 0 & 0.0 \\
\hline Staph. aureus + E-coli & 0 & 0.0 & 0 & 0.0 & 1 & 5.0 & 0 & 0.0 & 1 & 8.3 & 1 & 10.0 \\
\hline Total & 12 & 60.0 & 11 & 55.0 & 10 & 50.0 & 9 & 45.0 & 4 & 33.3 & 3 & 30.0 \\
\hline $\mathrm{MCp}$ & \multicolumn{4}{|c|}{0.221} & \multicolumn{4}{|c|}{0.805} & \multicolumn{4}{|c|}{0.272} \\
\hline
\end{tabular}

MCp: p for Monte Carlo test

\# the remaining numbers of patients in each type of technique was discharged before 3rd culture.

*More than one answer for each patient 
Table (7): Relationship between the studied patients in both conventional occlusive dressing technique and polythene gloves dressing technique per week and wound pain

\begin{tabular}{|c|c|c|c|c|c|c|c|c|c|c|c|c|}
\hline \multirow{3}{*}{ Perception of pain } & \multicolumn{4}{|c|}{$1^{\text {st }}$ Week } & \multicolumn{4}{|c|}{$2^{\text {nd }}$ Week } & \multicolumn{4}{|c|}{$3^{\text {rd }}$ Week } \\
\hline & \multicolumn{2}{|c|}{$\begin{array}{l}\text { Conventional } \\
\text { technique } \\
(\mathrm{n} 0=20)\end{array}$} & \multicolumn{2}{|c|}{$\begin{array}{l}\text { Polythene } \\
\text { gloves } \\
\text { Technique } \\
\text { (no=20) }\end{array}$} & \multicolumn{2}{|c|}{$\begin{array}{l}\text { Conventional } \\
\text { technique } \\
(\mathrm{n} 0=20)\end{array}$} & \multicolumn{2}{|c|}{$\begin{array}{l}\text { Polythene } \\
\text { gloves } \\
\text { Technique } \\
\text { (no=20) }\end{array}$} & \multicolumn{2}{|c|}{$\begin{array}{c}\text { Conventional } \\
\text { technique } \\
(\mathrm{n} 0=4) \#\end{array}$} & \multicolumn{2}{|c|}{$\begin{array}{l}\text { Polythene } \\
\text { gloves } \\
\text { Technique } \\
(\mathrm{n} 0=2) \#\end{array}$} \\
\hline & No. & $\%$ & No. & $\%$ & No. & $\%$ & No. & $\%$ & No. & $\%$ & No. & $\%$ \\
\hline $\begin{array}{l}\text { Pain during two dre } \\
\text { techniques }\end{array}$ & & & & & & & & & & & & \\
\hline Yes & 20 & 100.0 & 5 & 25.0 & 16 & 80.0 & 0 & 0.0 & 3 & 75.0 & 0 & 0.0 \\
\hline $\mathrm{N}_{0}$ & 0 & 0.0 & 15 & 75.0 & 4 & 20.0 & 20 & 100.0 & 1 & 25.0 & 2 & 100.0 \\
\hline Total & 20 & 100.0 & 20 & 100.0 & 20 & 100.0 & 20 & 100.0 & 4 & 100.0 & 2 & 100.0 \\
\hline FEp & \multicolumn{4}{|c|}{$<0.001^{*}$} & \multicolumn{4}{|c|}{$<0.001^{*}$} & \multicolumn{4}{|c|}{$0.048^{*}$} \\
\hline
\end{tabular}

FEp: $p$ value for Fisher Exact test

* Statistically significant at $p \leq 0.05$

\# the remaining numbers of patients in each type of technique was discharged in the $3^{\text {rd }}$ week. 
Table (8): Relationship between studied patients in both conventional occlusive dressing technique and polythene gloving dressing techniques regarding cost of dressing and time consumed until complete healing

\begin{tabular}{|l|c|c||}
\hline & $\begin{array}{c}\text { Conventional occlusive } \\
\text { dressing techniques } \\
(\mathbf{n o = 2 0})\end{array}$ & $\begin{array}{c}\text { Polythene gloving } \\
\text { dressing techniques } \\
(\mathbf{n o = 2 0})\end{array}$ \\
\hline Cost of dressing (ponds) & $437.00-969.00$ & $338.00-699.50$ \\
Range & $715.65 \pm 166.93$ & $508.93 \pm 130.59$ \\
Rean \pm SD & $2.50-9.80$ & $1.61-3.50$ \\
Time consumed (hours) & $5.07 \pm 2.20$ & $2.49 \pm 0.68$ \\
\hline
\end{tabular}


Conventional Occlusive Dressing versus Polythene Gloving on Burned Hands

Table (9): Relationship between studied patients in both the conventional occlusive dressing technique and polythene gloves dressing technique of regarding DLAs

\begin{tabular}{|c|c|c|c|c|c|c|c|c|c|c|c|c|c|c|c|c|c|c|c|c|}
\hline \multirow{3}{*}{ DLAs } & \multicolumn{4}{|c|}{$\overline{5^{\text {st }} \text { Day }}$} & \multicolumn{4}{|c|}{$9^{9^{\text {th }} \text { Day }}$} & \multicolumn{4}{|c|}{$13^{\text {th }}$ Day } & \multicolumn{4}{|c|}{$17^{\text {th }}$ Day } & \multicolumn{4}{|c|}{$\overline{22^{\text {st }} \text { Day }}$} \\
\hline & \multicolumn{2}{|c|}{$\begin{array}{c}\text { Conventional } \\
(\mathrm{n} 0=20)\end{array}$} & \multicolumn{2}{|c|}{$\begin{array}{c}\text { Polythene } \\
\text { gloves } \\
\text { (no=20) }\end{array}$} & \multicolumn{2}{|c|}{$\begin{array}{c}\text { Conventional } \\
(\mathrm{n} 0=20)\end{array}$} & \multicolumn{2}{|c|}{\begin{tabular}{|c}
$\begin{array}{c}\text { Polythene } \\
\text { gloves } \\
(\mathrm{n} 0=20)\end{array}$ \\
\end{tabular}} & \multicolumn{2}{|c|}{$\begin{array}{c}\text { Conventional } \\
(\mathrm{n} 0=20)\end{array}$} & \multicolumn{2}{|c|}{$\begin{array}{c}\text { Polythene } \\
\text { gloves } \\
\text { (no=20) }\end{array}$} & \multicolumn{2}{|c|}{$\begin{array}{c}\text { Conventional } \\
(\mathrm{n} 0=12) \#\end{array}$} & \multicolumn{2}{|c|}{$\begin{array}{c}\text { Polythene } \\
\text { gloves } \\
(\mathrm{n} 0=10) \#\end{array}$} & \multicolumn{2}{|c|}{$\begin{array}{c}\text { Conventional } \\
(\mathrm{n} 0=4) \#\end{array}$} & \multicolumn{2}{|c|}{$\begin{array}{c}\text { Polythene } \\
\text { gloves } \\
\text { (n0=2)\# }\end{array}$} \\
\hline & No. & $\%$ & No. & $\%$ & No. & $\%$ & No. & $\%$ & No. & $\%$ & No. & $\%$ & No. & $\%$ & No. & $\%$ & No. & $\%$ & No. & $\%$ \\
\hline Dressing gown & & & & & & & & & & & & & & & & & & & & \\
\hline & 0 & 0.0 & 3 & 15.0 & 2 & 10.0 & 4 & 20.0 & 10 & 50.0 & 16 & 80.0 & 9 & 75.0 & 9 & 90.0 & 4 & $\begin{array}{c}100 . \\
0\end{array}$ & 2 & $\begin{array}{c}100 \\
0\end{array}$ \\
\hline Done di & 5 & 25.0 & 11 & 55.0 & 9 & 45.0 & 15 & 75.0 & 5 & 25.0 & 4 & 20.0 & 3 & 25.0 & 1 & 10.0 & 0 & 0.0 & 0 & 0.0 \\
\hline Not do & 15 & 75.0 & 6 & 30.0 & 9 & 45.0 & 1 & 5.0 & 5 & 25.0 & 0 & 0.0 & 0 & 0.0 & 0 & 0.0 & 0 & 0.0 & 0 & 0.0 \\
\hline Total & 20 & 100 & 20 & 100 & 20 & 100 & 20 & 100 & 20 & 100 & 20 & 100 & 12 & 100 & 10 & 100 & 4 & 100 & 2 & 100 \\
\hline MCp & \multicolumn{4}{|c|}{$0.006^{*}$} & \multicolumn{4}{|c|}{$0.014^{*}$} & \multicolumn{4}{|c|}{0.052} & \multicolumn{4}{|c|}{0.182} & \\
\hline $\begin{array}{l}\text { Turning on/off } \\
\text { taps }\end{array}$ & & & & & & & & & & & & & & & & & & & & \\
\hline Done adequately & 1 & 5.0 & 7 & 35.0 & 5 & 25.0 & 15 & 75.0 & 10 & 50.0 & 18 & 90.0 & 8 & 66.7 & 8 & 80.0 & 4 & $\begin{array}{c}100 . \\
0\end{array}$ & 2 & $\begin{array}{c}100 . \\
0\end{array}$ \\
\hline Done difficulty & 9 & 45.0 & 12 & 60.0 & 13 & 65.0 & 5 & 25.0 & 9 & 45.0 & 2 & 10.0 & 4 & 33.3 & 2 & 20 & 0 & 0.0 & 0 & 0.0 \\
\hline Not don & 10 & 50.0 & 1 & 5.0 & 2 & 10.0 & 0 & 0.0 & 1 & 5.0 & 0 & 0.0 & 0 & 0.0 & 0 & 0.0 & 0 & 0.0 & 0 & 0.0 \\
\hline Total & 20 & 100 & 20 & 100 & 20 & 100 & 20 & 100 & 20 & 100 & 20 & 100 & 12 & 100 & 10 & 100 & 4 & 100 & 2 & 100 \\
\hline $\mathrm{MCp}$ & \multicolumn{4}{|c|}{$0.001^{*}$} & \multicolumn{4}{|c|}{$0.006^{*}$} & \multicolumn{4}{|c|}{$0.012^{*}$} & \multicolumn{4}{|c|}{0.605} & \\
\hline Brush $\mathrm{t}$ & & & & & & & & & & & & & & & & & & & & \\
\hline Done & 2 & 10.0 & 7 & 35.0 & 5 & 25.0 & 12 & 60.0 & 9 & 45.0 & 18 & 90.0 & 9 & 75.0 & 9 & 90.0 & 4 & $\begin{array}{c}100 . \\
0\end{array}$ & 2 & $\begin{array}{c}100 . \\
0\end{array}$ \\
\hline Done difficulty & 10 & 50.0 & 12 & 60.0 & 7 & 35.0 & 8 & 40.0 & 9 & 45.0 & 2 & 10.0 & 3 & 25.0 & 1 & 10.0 & 0 & 0.0 & 0 & 0.0 \\
\hline Not done & 8 & 40.0 & 1 & 5.0 & 8 & 40.0 & 0 & 0.0 & 2 & 10.0 & 0 & 0.0 & 0 & 0.0 & 0 & 0.0 & 0 & 0.0 & 0 & 0.0 \\
\hline Total & 20 & 100 & 20 & 100 & 20 & 100 & 20 & 100 & 20 & 100 & 20 & 100 & 12 & 100 & 10 & 100 & 4 & 100 & 2 & 100 \\
\hline Test of sig. & \multicolumn{4}{|c|}{$\mathrm{MCp}=0.021^{*}$} & \multicolumn{4}{|c|}{$\chi^{2}=10.949^{*}, p=0.004$} & & $\mathrm{MCp}=$ & $=0.008^{2}$ & & & $\mathrm{MCp}=$ & 0.868 & & & & & \\
\hline
\end{tabular}

MCp: p for Monte Carlo test

$\chi 2$ : Chi-square test

* Statistically significant at $p \leq 0.05$

\# the remaining numbers of patients in each type of technique were discharged in the 17th Day and 21st Day. 
Conventional Occlusive Dressing versus Polythene Gloving on Burned Hands

Table (9): "Continued"

\begin{tabular}{|c|c|c|c|c|c|c|c|c|c|c|c|c|c|c|c|c|c|c|c|c|}
\hline \multirow{3}{*}{ DLAs } & \multicolumn{4}{|c|}{$5^{5^{\text {st }} \text { Day }}$} & \multicolumn{4}{|c|}{$9^{9^{\text {th }} \text { Day }}$} & \multicolumn{4}{|c|}{$\overline{13^{\text {th }} \text { Day }}$} & \multicolumn{4}{|c|}{$\overline{17^{\text {th }} \text { Day }}$} & \multicolumn{4}{|c|}{$22^{2{ }^{\text {st }} \text { Day }}$} \\
\hline & \multicolumn{2}{|c|}{\begin{tabular}{|c} 
Conventional \\
$(\mathrm{n} 0=20)$
\end{tabular}} & \multicolumn{2}{|c|}{$\begin{array}{l}\text { Polythene } \\
\text { gloves } \\
\text { (no }=20)\end{array}$} & \multicolumn{2}{|c|}{$\begin{array}{c}\text { Conventional } \\
(\mathrm{n} 0=20)\end{array}$} & \multicolumn{2}{|c|}{$\begin{array}{c}\text { Polythene } \\
\text { gloves } \\
(\text { no=20) }\end{array}$} & \multicolumn{2}{|c|}{$\begin{array}{c}\text { Conventional } \\
(\mathrm{n} 0=20)\end{array}$} & \multicolumn{2}{|c|}{$\begin{array}{l}\text { Polythene } \\
\text { gloves } \\
\text { (no }=20)\end{array}$} & \multicolumn{2}{|c|}{$\begin{array}{l}\text { Conventional } \\
(\mathrm{n} 0=12) \#\end{array}$} & \multicolumn{2}{|c|}{$\begin{array}{c}\text { Polythene } \\
\text { gloves } \\
(\mathrm{n} 0=10) \#\end{array}$} & \multicolumn{2}{|c|}{$\begin{array}{c}\text { Conventional } \\
(\mathrm{n} 0=4) \#\end{array}$} & \multicolumn{2}{|c|}{$\begin{array}{c}\text { Polythene } \\
\text { gloves } \\
\text { (no=2)\# }\end{array}$} \\
\hline & No. & $\%$ & No. & $\%$ & No. & $\%$ & No. & $\%$ & No. & $\%$ & No. & $\%$ & No. & $\%$ & $\mathrm{~N}_{0}$. & $\%$ & No. & $\%$ & No. & $\%$ \\
\hline \multirow{2}{*}{$\begin{array}{l}\text { Cutting bread } \\
\text { Done adequalty }\end{array}$} & & & & & & & & & & & & & & & & & & & & \\
\hline & 3 & 15.0 & 11 & 55.0 & 9 & 45.0 & 16 & 80.0 & 14 & 70.0 & 19 & 95.0 & 10 & 83.3 & 10 & $\begin{array}{c}100 . \\
0\end{array}$ & 4 & $\begin{array}{c}100 . \\
0\end{array}$ & 2 & $\begin{array}{c}100 . \\
0\end{array}$ \\
\hline Done difficulty & 11 & 55.0 & 8 & 40.0 & 7 & 35.0 & 4 & 20.0 & 5 & 25.0 & 1 & 5.0 & 2 & 16.7 & 0 & 0.0 & 0 & 0.0 & 0 & 0.0 \\
\hline Not done & 6 & 30.0 & 1 & 5.0 & 4 & 20.0 & 0 & 0.0 & 1 & 5.0 & 0 & 0.0 & 0 & 0.0 & 0 & 0.0 & 0 & 0.0 & 0 & 0.0 \\
\hline Total & 20 & 100 & 20 & 100 & 20 & 100 & 20 & 100 & 20 & 100 & 20 & 100 & 12 & 100 & 10 & 100 & 4 & 100 & 2 & 100 \\
\hline MCp & \multicolumn{4}{|c|}{$0.019^{*}$} & \multicolumn{4}{|c|}{$0.030^{*}$} & \multicolumn{4}{|c|}{0.090} & \multicolumn{4}{|c|}{0.481} & \\
\hline Use spoonful & & & & & & & & & & & & & & & & & & & & \\
\hline Done ad & 4 & 20.0 & 7 & 35.0 & 4 & 20.0 & 7 & 35.0 & 11 & 55.0 & 18 & 90.0 & 9 & 75.0 & 9 & 90.0 & 4 & $\begin{array}{c}100 . \\
0\end{array}$ & 2 & $\begin{array}{c}100 . \\
0\end{array}$ \\
\hline Done difficulty & 6 & 30.0 & 12 & 60.0 & 9 & 45.0 & 12 & 60.0 & 7 & 35.0 & 2 & 10.0 & 3 & 25.0 & 1 & 10.0 & 0 & 0.0 & 0 & 0.0 \\
\hline Not done & 10 & 50.0 & 1 & 5.0 & 7 & 35.0 & 1 & 5.0 & 2 & 10.0 & 0 & 0.0 & 0 & 0.0 & 0 & 0.0 & 0 & 0.0 & 0 & 0.0 \\
\hline Total & 20 & 100 & 20 & 100 & 20 & 100 & 20 & 100 & 20 & 100 & 20 & 100 & 12 & 100 & 10 & 100 & 4 & 100 & 2 & 100 \\
\hline $\mathrm{MCp}$ & \multicolumn{4}{|c|}{$0.009^{*}$} & \multicolumn{4}{|c|}{$0.030^{*}$} & \multicolumn{4}{|c|}{$0.035^{*}$} & \multicolumn{4}{|c|}{0.594} & \\
\hline Moving & & & & & & & & & & & & & & & & & & & & \\
\hline Done ad & 3 & 15.0 & 11 & 55.0 & 5 & 25.0 & 16 & 80.0 & 15 & 75.0 & 19 & 95.0 & 9 & 75.0 & 9 & 90.0 & 4 & $\begin{array}{c}100 . \\
0\end{array}$ & 2 & $\begin{array}{c}100 . \\
0\end{array}$ \\
\hline Done difficulty & 13 & 65.0 & 9 & 45.0 & 11 & 55.0 & 4 & 20.0 & 5 & 25.0 & 1 & 5.0 & 3 & 25.0 & 1 & 10.0 & 0 & 0.0 & 0 & 0.0 \\
\hline Not done & 4 & 20.0 & 0 & 0.0 & 4 & 20.0 & 0 & 0.0 & 0 & 0.0 & 0 & 0.0 & 0 & 0.0 & 0 & 0.0 & 0 & 0.0 & 0 & 0.0 \\
\hline Total & 20 & 100 & 20 & 100 & 20 & 100 & 20 & 100 & 20 & 100 & 20 & 100 & 12 & 100 & 10 & 100 & 4 & 100 & 2 & 100 \\
\hline $\mathrm{MCp}$ & \multicolumn{4}{|c|}{$0.008^{*}$} & & 0.0 & & & & & 82 & & & & 94 & & & & & \\
\hline
\end{tabular}

MCp: p for Monte Carlo test

*: Statistically significant at $\mathrm{p} \leq 0.05$

\#the remaining numbers of patients in each type of technique was discharged in the $17^{\text {th }}$ Day and $21^{\text {st }}$ Day. 
Conventional Occlusive Dressing versus Polythene Gloving on Burned Hands

Table (9): "Continued"

\begin{tabular}{|c|c|c|c|c|c|c|c|c|c|c|c|c|c|c|c|c|c|c|c|c|}
\hline \multirow{3}{*}{ DLAs } & \multicolumn{4}{|c|}{$\overline{5^{\text {th }} \text { Day }}$} & \multicolumn{4}{|c|}{$9^{\text {th }}$ Day } & \multicolumn{4}{|c|}{$13^{\text {th }}$ Day } & \multicolumn{4}{|c|}{$17^{\text {th }}$ Day } & \multicolumn{4}{|c|}{$21^{\mathrm{st}}$ Day } \\
\hline & \multicolumn{2}{|c|}{$\begin{array}{c}\text { Conventional } \\
(\mathrm{n} 0=20)\end{array}$} & \multicolumn{2}{|c|}{$\begin{array}{c}\text { Polythene } \\
\text { gloves } \\
\text { (no=20) }\end{array}$} & \multicolumn{2}{|c|}{$\begin{array}{c}\text { Conventional } \\
(\mathrm{n} 0=20)\end{array}$} & \multicolumn{2}{|c|}{$\begin{array}{c}\text { Polythene } \\
\text { gloves } \\
\text { (no=20) }\end{array}$} & \multicolumn{2}{|c|}{$\begin{array}{c}\text { Conventional } \\
(\mathrm{n} 0=20)\end{array}$} & \multicolumn{2}{|c|}{$\begin{array}{c}\text { Polythene } \\
\text { gloves } \\
\text { (no=20) }\end{array}$} & \multicolumn{2}{|c|}{$\begin{array}{l}\text { Conventional } \\
(\mathrm{n} 0=12) \#\end{array}$} & \multicolumn{2}{|c|}{\begin{tabular}{|c|}
$\begin{array}{c}\text { Polythene } \\
\text { gloves } \\
(\mathrm{n} 0=10) \#\end{array}$ \\
\end{tabular}} & \multicolumn{2}{|c|}{$\begin{array}{l}\text { Conventional } \\
(\mathrm{n} 0=4) \#\end{array}$} & \multicolumn{2}{|c|}{$\begin{array}{c}\text { Polythene } \\
\text { gloves } \\
(\text { no=2)\# }\end{array}$} \\
\hline & No. & $\%$ & No. & $\%$ & No. & $\%$ & No. & $\%$ & No. & $\%[1$ & No. & $\%$ & No. & $\%$ & No. & $\%$ & $\mathrm{~N}_{0}$. & $\%$ & No. & $\%$ \\
\hline Putting in/out electric plugs & & & & & & & & & & & & & & & & & & & & \\
\hline Done adequately & 3 & 15.0 & 126 & 60.0 & 4 & 20.0 & 178 & 85.0 & 14 & 70.0 & 19 & 95.0 & 10 & 83.3 & 10 & 100. & 4 & $\begin{array}{c}100 . \\
0\end{array}$ & 2 & 100. \\
\hline Done difficulty & 4 & 20.0 & 7 & 35.0 & 12 & 40.0 & 3 & 15.0 & 6 & 30.0 & 1 & 5.0 & 2 & 16.7 & 0 & 0.0 & 0 & 0.0 & 0 & 0.0 \\
\hline Not done & 10 & 50.0 & $1:$ & 5.0 & 4 & 20.0 & 0 & 0.0 & 0 & 0.0 & 0 & 0.0 & 0 & 0.0 & 0 & 0.0 & 0 & 0.0 & 0 & 0.0 \\
\hline Total & 20 & 100 & 201 & 100 & 20 & 100 & 20 & 100 & 20 & 100 & 20 & 100 & 12 & 100 & 10 & 100 & 4 & 100 & 2 & 100 \\
\hline $\mathrm{MCp}$ & \multicolumn{4}{|c|}{$0.001^{*}$} & \multicolumn{4}{|c|}{$<0.001^{*}$} & \multicolumn{4}{|c|}{0.091} & \multicolumn{4}{|c|}{0.481} & \\
\hline Turning & & & & & & & & & & & & & & & & & & & & \\
\hline Done adequately & 1 & 5.0 & 52 & 25.0 & 1 & 5.0 & 6 & 30.0 & 12 & 60.0 & 19 & 95.0 & 7 & 58.3 & 8 & 80.0 & 4 & 100. & 2 & 100. \\
\hline Done difficulty & 8 & 40.0 & 147 & 70.0 & 13 & 65.0 & 13 & 65.0 & 7 & 35.0 & 1 & 5.0 & 5 & 41.7 & 2 & 20.0 & 0 & 0.0 & 0 & 0.0 \\
\hline Not done & 11 & 55.0 & 1 & 5.0 & 6 & 30.0 & 1 & 5.0 & 1 & 5.0 & 0 & 0.0 & 0 & 0.0 & 0 & 0.0 & 0 & 0.0 & 0 & 0.0 \\
\hline Total & 20 & 100 & 20 & 100 & 20 & 100 & 20 & 100 & 20 & \begin{tabular}{|l|l|}
100 \\
\end{tabular} & \begin{tabular}{l|l}
20 & 1 \\
\end{tabular} & 100 & 12 & 100 & 10 & 100 & 4 & 100 & 2 & 100 \\
\hline $\mathrm{MCp}$ & \multicolumn{4}{|c|}{$0.001^{*}$} & \multicolumn{4}{|c|}{$0.035^{*}$} & \multicolumn{4}{|c|}{$0.019^{*}$} & \multicolumn{4}{|c|}{0.381} & \\
\hline
\end{tabular}

MCp: p for Monte Carlo test

$*$ Statistically significant at $p \leq 0.05$

\#the remaining numbers of patients in each type of technique was discharged in the $17^{\text {th }}$ Day and $21^{\text {st }}$ Day. 


\section{References}

1. Nour W. Effect of nutritional regimen for moderate burn patients on graft take. Unpublished Doctoral Dissertation. Faculty of nursing; University of Alexandria. 2003.

2. Rosdahle C, Kowalski M. Textbook of basic nursing. $8^{\text {th }}$ ed. Philadelphia: Lippincott Williams \& Wilkins, 2003.

3. Lewis $\mathrm{S}$, Heitkemper $\mathrm{M}$, Dirksen $\mathrm{S}$. Medical-surgical nursing: Assessment and management of clinical problems. $6^{\text {th }}$ ed. London: Mosby, 2004; 515-39.

4. McCann J, Nieginski G, Moreau D, Rebinson J, Putterman A, Diehl T, Sciaira J, Caplin M, Bilotta K, Dezego T. Straights in Medical-surgical. Sydney: Lippincott Williams \& Wilkins, 2004; 396-8.

5. Phillips N. Berrgy \& Kohn's operating room technique. $10^{\text {th }}$ ed. United States: Mosby, 2004; 831-6.

6. McLean B, Simmerman J, Baldisseri M, Dellinger R. Fundamentals of critical care medicine. $4^{\text {th }}$ ed. United States: Society of critical medicine, 2007.

7. Timby B, Smith N. Introductory Medical-surgical nursing. $8^{\text {th }}$ ed. Philadelphia: Lippincott Williams \& Wilkins, 2003; 1146-61.

8. O'shea R, Porter K. Principles and practice of trauma nursing. New York: Elsevier Churchill Livingstone, 2005; 497-511.

9. McCann J, Moreau D, Robinson J, Putterman A, Ludwicki M, Sciarra J, Stocksiager J, Howard J, Theodore R, Witting P. Wound care made: incredibly easy. London: Lippincott Williams \& Wilkins, 2003; 14- 25, 53-65.

10. Shukla V, Mani R, Teot L, Pradhan S. Management of wound healing. New Delhi: Jaypee Brothers, 2007; 36.
11. Linda G. Phillip S. Wound healing. Clinics in plastic surgery, 2003; 30(1).

12. Hampson G. Practice nurse handbook. $4^{\text {th }}$ ed. Great Britain: Blackewll Science, 2002; 56-61, 111.

13. Perry A, Potter P. Clinical nursing skills and techniques. $6^{\text {th }}$ ed. United States: Mosby, 2006; 1229-34.

14. Morisan M. A color guide to the nursing: Management of wounds. $10^{\text {th }}$ ed. London: Wolfe publishing limited, 2004; 1-30, 56-69.

15. Black J, Jacobs E. Medical-surgical nursing: Clinical management for continuity of care. $5^{\text {th }}$ ed. Philadelphia: W.B. Saunders, 1997; 426-46.

16. Settle J. Principles and practice of burns management. San Francisco: Churchill Livingstone, 1996; 64.

17. Trott A. Wounds and lacerations: Emergency care and closure. $3^{\text {rd }}$ ed. Pennsylvania: Elsevier Mosby, 2005; 22- 31.

18. Morton P, Fontaine D, Hudak C, Gallob. Critical care nursing: A holistic approach. $8^{\text {th }}$ ed. United States: Lippincott Williams \& Wilkins, 2005; 1213- 19, 1226-47.

19. Abd El-Mohsen S. A Clinical study of different methods of early management of deep and deep dermal burned hands. Unpublished Master Dissertation. Faculty of medicine; University of Alexandria. 2008.

20. Gahankari D, Dyrne S, Rudd M, Pegg S. Review of out comes in acute hands burns treated at Royal Brisbane hospital. 2004. Available at: http://www.sciencedirect.com

21. Limmer D, O'keefe M. Emergency care. $10^{\text {th }}$ ed. United State: Upper Saddle River, 2005; 613-9. 
22. Atiyeh B, Ghanimeh G, Nasser A, Musharrafieh R. Surgical management of the burned hand. Annals of burns and fire disaster, 2000; 13(4): 230.

23. Barillo D, Paulsen S. Management of burns to the hand. Wound, 2003; 15(1): 4-9.

24. Sheriden R. Acute hand burns in children. Ann. surg., 1999; 229(4): 558564.

25. Masellis M, Gunn S. The management of mass burn casualties and fire. 2007 Available at: http://www.springerlink.com.

26. Steven D, Feinbery M, Rachel M. Hand injuries in the workplace professionals. CWCE, 2000, February- March; 1-10.

27. Melvin A, Samuel M. hand burns. 2004 Available at: http://www.springerlink.com

28. Stead L, Vaughn C, Gibbons T, Ewan $\mathrm{H}$, Carcel M, O'brien C, McGlaughlin H, Brennan E. The lippincott: Manual of nursing practice. $7^{\text {th }}$ ed. New York: Lippincott, 2001; 1045-60.

29. Smeltzer S, Bare B. Brunner and Suddarth's textbook of Medical-surgical nursing. $8^{\text {th }}$ ed. New York: LippincottRaven Publishers, 1996; 413-9: 154573.

30. Smeltzer S, Bara B. Brunner \& Suddarth's Textbook of Medicalsurgical nursing. $10^{\text {th }}$ ed. London: Lippincott Williams \& Wilkins, 2004; 1704-24.

31. Raftarg A. Surgery. $2^{\text {nd }}$ ed. London: Churchill Livingstone, 2001; 460.

32. Henley M, Martin D. The management of mass burn causalities and fire disasters proceedings of the first international conference on burns and fire disasters.2007; 288-91.
33. Hogan M, Madayag T. Medicalsurgical nursing: reviews rationales. London: Pearson prentice Hall, 2004: 374-7, 406-7.

34. Garrison S. Handbook of physical medicine and rehabilitation: the basics. $2^{\text {nd }}$ ed. Philadelphia: Lippincott Williams \& Wilkins, 2003; 67-79.

35. Elmelegy O. The use of early physical rehabilitative therapy in minimizing contracture deformity of the burned hand. Unpublished Doctoral Dissertation. Faculty of nursing; University of Tanta. 2006.

36. Abd-El-Rahman E. The effect of splinting on the occurrence of contracture in burned lower limbs. Unpublished master dissertation. Faculty of nursing; university of Alexandria. 2008.

37. Khalil M. Conventional dressing versus early exposure after major abdominal surgeries. Unpublished Master Dissertation. Faculty of nursing; University of Alexandria. 2008.

38. Potter P, Perry A. Basic nursing: A critical thinking approach. $4^{\text {th }}$. Philadelphia: Mosby, 1999; 558-95.

39. Ragab N. Effectiveness of two dressing techniques on the healing of recent moderately burn wounds. Unpublished Doctoral Dissertation. Faculty of nursing; University of Alexandria. 2002.

40. El-Shatby A. Comparison between two dressing techniques on the healing of grade I diabetic foot ulcer. Unpublished Doctoral Dissertation. Faculty of nursing; University of Alexandria. 2003.

41. Hoeman S. Rehabilitation nursing: Process, application and outcomes. $3^{\text {rd }}$ ed. London: Mosby, 2002; 282-304. 
42. Monahan F, Sands J, Neighbors M, Marek J, Green C. Phipps' Medicalsurgical nursing: Health and illness perspectives. China: Mosby, 2007; 1911-41.

43. Edmond M. International textbook of diabetes mellitus. New York: Jhon Wiley and Sons, 2001; 1535-47.
44. Abdel-Dayem S, Zaki H, Moisry N, Sharaf S. The adult burn patient: identification of nursing diagnosis. The Medical Journal, Cairo University. 1992.

45. Ferguson D, Fodden D. Accident and emergency medicine. $4^{\text {th }}$ ed. London: Churchill Livingstone, 2000; 123. 